\title{
The Relationship between English Language Skills and Learning Needs of Secondary School Students
}

\author{
(D)Aida Kairienè Mg. educ. \\ Vytautas Magnus University, Lithuania \\ aida929@gmail.com
}

\begin{abstract}
Students learn English with certain motives. Many students seek to improve their careers, others seek to gain confidence, and others plan to live abroad. Thus, the problematic question arises: how do English language skills and learning needs of secondary school students relate to each other? The research aim is to designate the relationship between English language skills and learning needs of secondary school students. The methods of descriptive statistics were used. The Spearman rank correlation coefficient was applied. Mostly the medium correlation and a weak correlation were dominated between English language skills and learning needs. The analysis disclosed that students give more priority to receptive skills reading and listening than to communicative - speaking and writing skills.
\end{abstract}

Keywords: English language skills, learning needs, secondary education.

\section{Introduction}

Lithuania's international and intercultural cooperation between the countries, the process of integration into the European Union and other international organizations, and the changing social and political situation in Lithuania and in the world raise new quality requirements for foreign language learning. Nowadays, educational institutions must train objectively and critically thinking citizens of the State. The Council Recommendation on Key Competences for Lifelong Learning emphasizes strengthening the functioning of multilingual competence. At the heart of this competence is the ability to use different languages properly and effectively in communication. It is based on the ability to understand, express, and interpret concepts, thoughts, feelings, facts, and opinions in both oral and written form (European Commission, 2018). Teaching a foreign language (English) means that English is taught in a country where English is treated as a "second language", for example, foreign language (English language), it means learning other languages than the mother tongue and it is a part of the curriculum (Lin, 2017). In Lithuania, this is regulated by the secondary school language program, which is used as a guide for the teachers.

Good language learners are willing to take risks, learn from their mistakes. On the other hand, good learners also use their first language skills when learning a second language. Z.V. Zhang (2020) argues that multi-faceted construct of student engagement encompasses major components in language learning, and show that engagement is essential to successful language learning. This is encouraging for foreign language teachers as they can provide instructional support and create an optimal learning environment to facilitate student's learning. An important feature of good learners' language is independence.

The English learning of secondary school students results in developing listening, reading, writing, and speaking skills. Nowadays authors (Manegre, Gutiérrez-Colón, 2020; Meinawati et al., 2020; Molway, Mutton, 2019; Naidionova, Ponomarenko, 2018) analyse key foreign language skills. L. Molway and M. Mutton (2019) disclose that students who received intervention training in reading strategies were considerably more likely than their peers to attempt the most challenging questions on the reading assessment. M. Manegre and M. Gutiérrez-Colón (2020) note that participating in knowledge building forums improved writing skills (grammar, syntactic structure, and accuracy) in the foreign language and comprehension of the material in the foreign language. J.J. Horgan (2017) suggests analysing students' experiences through written self-reflection because it allows making changes to the curriculum. According to A.V. Naidionova and O.G. Ponomarenko (2018) podcasts can be effectively used for motivating student interest in listening to English and providing them with exposure to native speakers' speech in authentic contexts. On the other hand, E. Meinawati, D.D. Harmoko, N.A. Rahmah, and N. Dewi suggest using YouTube as a media can be a good alternative media for teaching speaking in the class (Meinawati et al., 2020). In this way, students are speaking more expressive and don't have to worry about the phrases they use when speaking. Thus, the development of all these skills is the basis of language learning. 
According to the classical theory of A.H. Maslow (2006), motivation is a constant and complex process, never-ending, and changing. The same behaviour can be motivated by different motives. Moreover, motivation is a psychological process that gives direction to an activity; it is an internal impulse to user needs. Needs, according to J.C. Richards (2001, 54), "the differences between what a student can presently do in a language and what he should be able to do". Students are constantly motivated by needs. R.C. Gardner $(2010,168)$ claims "motivation to learn a second language is influenced by group-related, context- related attitude, integrativeness, and attitudes towards learning situations respectively". The author's integrative motivation is the most suitable for language learning. The author defines integrativeness as "it is not a conscious decision on the part of the individual and ... individuals may not be aware of it ... The rationale underlying integrative motivation is that emotional factors can influence behaviour, sometimes in ways that are not even perceived by the individual concerned" (Gardner, 2010, 223-224). Gardner's theory shows that second language learning motivation consists of three components motivational intensity; a desire to learn the language, and attitudes towards learning the language. Needs are related to motivation, needs arise first, and then motivation arises into learners' minds. R. Gonzales and M.Y. Lopez (2016) distinguished career-economic, cultural understanding, communication, and collaboration, self-satisfaction, selfconfidence, and cultural integration needs. Career - economic - is a need that is related to careers, finding a better job, financial benefits. Cultural understanding is a need that helps to understand the similarities and differences of another culture. Self-satisfaction need brings joy in learning English, and especially activities such as reading books, watching movies in English. Self-confidence need is a need that raises self-esteem. Cultural integration need is a need when learning English occurs to participate in the life of another culture. Students learn English with certain motives. Some seek to improve their careers, others seek to gain confidence, and others plan to live abroad. T.M. Thu (2009) states that students learn English through reading, listening, writing, and speaking skills. Thus, a problematic question arises: how do English language skills and learning needs of secondary school students relate to each other?

The aim of the research - to designate the relationship between English language skills and learning needs of secondary school students.

In accordance with the aim of the study, the following objectives were set: a) to identify the relationship between English language skills and learning needs of secondary school students by using Spearman's rank correlation; b) to analyse the relationship between English language skills and learning needs of secondary school students.

\section{Methodology}

Research question - what is the relationship between English language skills and learning needs of secondary school students?

Sample. A target criterion sample. Targeted selection is such a selection when the researcher selects elements into the sampling set depending on the purpose of the research and is selected according to certain criteria or decisions (Rupšiene, Rutkienè, 2016). The one who can provide meaningful information about the subject is selected. In this case, foreign (English) language learning is studied, so the target group is 12th grade students who learn English. The representative sample of the research is 93 students of 12th grade from Lithuanian secondary schools. According to gender 29 boys and 64 girls participated in the study. The average age is 18 years.

Methodological instrument. The T.M. Thu (2009, 57-58) questionnaire was applied to explore English language skills. A total of twenty statements were provided for 5 statements for each category: reading, writing, listening, and speaking. R. Gonzales and M.Y. Lopez (2016, 23) foreign language learning motivation questionnaire was adapted to learning needs. A total of thirty statements were provided for 5 statements for each category: career-economic, cultural understanding, communication and collaboration, self-satisfaction, self-confidence, and cultural integration needs. A 6-point scale was used: strongly disagree, disagree, disagree more than agree, agree more than disagree, agree, strongly agree. It was chosen because it is convenient and according to L. Rupšienè and A. Rutkienè (2016), it can be transformed into other scales (two or three-point scale) and this allows analysing the data using more diverse statistical methods.

Research ethics. The study according to K. Kardelis (2002) determines the main elements of research ethics as competence, volunteering, full information, and understanding. The questionnaire was intended for a $12^{\text {th }}$ 
grade student of age 18, so parental consent was not required. Voluntary participation in the study was ensured and confidentiality was ensured, the respondent did not have to provide either name or surname.

Data analysis. Statistical analysis was performed using "Social Sciences Statistics Package" (SPSS 17) for Windows. The methods of descriptive statistics were used. In this research, the internal compatibility was measured using Cronbach's $\alpha$ criterion. To designate the relationship between English language skills and learning needs, the Spearman's rank correlation was applied. According to J. Hauke and T. Kossowski (2011), Spearman's rank correlation coefficient is a nonparametric (distribution-free) rank statistic proposed by Charles Spearman as a measure of the strength of an association between two ranked variables. According to J. Lani (2010), a positive correlation coefficient indicates a positive relationship between the two variables (the larger A, the larger B), while a negative correlation coefficient expresses a negative relationship (the larger A, the smaller B). A correlation coefficient of 0 indicates that no relationship between the variables exists at all. In this case, a positive relationship between the two variables (the larger A, the larger B) has been analysed.

\section{Results and discussion}

One of the most important quality research characteristics and quality criteria of instruments, ensuring the accuracy and stability of measurements, in this study the reliability of the instrument is focused on the assessment of its internal compatibility and correlations between variables. The internal compatibility consistency approach is applied using Cronbach's $\alpha$ criterion. English language skills (block A) scale of Cronbach's $\alpha=0.872 ; M=81.63 ; S^{2}=250.734 ; S D=15.835 ; N=20$, so it can be assumed that the whole scale is a homogeneous and reliable measure. After checking each statement to see if removing it would increase Cronbach's $\alpha$, no correlation coefficient greater than Cronbach's $\alpha$ was found, so the scale is good and no variable needs to be removed from it. Learning needs (block $B$ ) scale Cronbach's $\alpha-0.939 ; M=136.15 ; S^{2}=576.173 ; S D=24.004 ; N=20$, therefore, the whole scale can be considered as a homogeneous and reliable measuring instrument. After checking each statement to see if removing it would increase Cronbach's $\alpha$, no correlation coefficient greater than Cronbach's $\alpha$ was found, so the scale is good and no variable needs to be removed from it.

\section{The relationship between English language skills and learning needs of secondary school students}

Spearman's rank correlation coefficient. Correlation values: up to 0.2 - very weak correlation; 0.2 to 0.4 - weak correlation; 0.4 to 0.7 - medium correlation; 0.7 to 0.9 strong correlation; more than 0.9 - very strong correlation (Williams, Monge, 2001). The significance level is chosen to be the lowest $p<0,001$.

T.M. Thu (2009) questionnaire was applied to explore English learning skills. A total of twenty statements were provided for 5 statements for each category: reading, writing, listening, and speaking. Here and below in the text will be used abbreviations such as SA1, SA2, and so on. Due to this reason, every single question of the questionnaire is presented. Reading skills statements: SA1 - When I get a dialogue task, I rehearse the future situation in my mind to make sure I can do it; SA2 - When I get a dialogue task, I rehearse a future situation with my classmate to make sure I can do it; SA3 - When I'm in a shop or cafe in my country, I try to imagine what I can say in English in this situation; SA4 When I don't know how to say in a foreign language, I try to say it in other ways; SA5 - When I don't know how to say in a foreign language, ask the interlocutor to help me do it. Writing skills statements: SA6 - When I am writing, I try to choose a topic that would allow me to use what I know rather than forcing me to use what I don't know; SA7 - Before I start writing an essay, I make a plan of what I will write about; SA8 - I write everything in draft first, then correct the mistakes and provide the final version of the text; SA9 - When writing, I use familiar words and grammar rules more than I search for most words in dictionaries; SA10 - I can choose the right pattern of text to write depending on its purpose, such as writing an invitation, writing the address correctly. Listening skills statements: SA11 - I try to guess if not everything I understand what was said in English; SA12 - When I don't understand what was said during the conversation, I explain to the interlocutor exactly what I didn't understand; SA13 - I try to use my knowledge of the world to understand conversations, TV or radio shows or movies in English; SA14 - When writing, I use familiar words and grammar rules more than I search for most words in dictionaries; SA15 - If I don't understand what it's all about, I try to listen further to hear a hint to help me understand what is meant. Reading skills statements: SA16 - I use my knowledge of the sequence of events to understand an excerpt from the text; SA17 -I use my knowledge of English 
to understand unclear part of the text; SA18 - I try to understand the meaning of unknown words in the text from the context; SA19 - I ask myself questions to check if I understand the text; SA20 - When I read unknown words in a dictionary, I think about the context in which they are used.

R. Gonzales, M.Y. Lopez (2016) motivation questionnaire was applied. A total of thirty statements were provided. Here and below in the text will be used abbreviations such as SB1, SB2, and so on. Due to this reason, every single question of the questionnaire is presented. The career-economic needs statements: SB1 - Knowing English language leads to a better job; SB2 - Knowing English leads to financial benefits; SB3 - Learning English is a preparation for my future profession; SB4 - Knowing English provides more opportunities after graduation; SB5 - Knowing English improves my career prospects. The cultural understanding need statements: SB6 - Knowing English will help me better understand other cultures; SB7 - I can understand more foreigners if I speak their language; SB8 Knowing English gives me confidence in understanding other cultures; SB9 - English language is important to me in understanding other cultures; SB10 - Knowledge of a foreign language broadens my horizons about other cultures. Communication and collaboration needs with foreigners' statements: SB11 - Knowing a foreign language helps to communicate with foreigners in their native language; SB12 - When I know a foreign language, I can speak to foreigners in their native language; SB13 Knowing a foreign language is easier to make connections with foreigners; SB14 - I am impressed when I hear a foreign language; SB15 - Knowing a foreign language is important when traveling to other countries. The self-satisfaction need statement: SB16 - I enjoy learning a foreign language when my friend brings me books in a foreign language; SB17 - I like to visit websites in a foreign language; SB18 - I like learning a foreign language because my friends like learning it; SB19 - I enjoy watching movies especially if they are in a foreign language; SB20 - I like learning a foreign language, in order pass the final exam. Self-confidence need statements: SB21 - I can communicate fluently in English in my classroom; SB22 - I like to communicate in English because I know it well; SB23 - I feel comfortable communicating in English in class; SB24 - I like learning English even though it's hard; SB25 - I am happy when the teacher notices my English progress in the classroom. Culture integration need statements: SB26 - I am learning a foreign language, to live in a foreign country; SB27 - I am learning a foreign language to communicate well with foreigners; SB28 - I study a foreign language because I am interested in the cultures of other countries; SB29 - Learning a foreign language helps me prepare for living in another country; SB30 - I am learning a foreign language to live in another culture.

\section{The relationship between English language skills and career-economic, cultural understanding needs}

The correlation between English skills and career-economic needs. The mostly correlate listening and reading skills (Table 1). A medium relationship was found between listening SA15 and all statements of career - economic need $(r=0.4-0.6 ; p=0.000(p<0.001))$. This shows that the more students listen to the talker, they more understand the language, and they are more motivated to prepare for a future profession by improving their career prospects and finding a better job by gaining financial benefits from it. Exploring the relationship between statement SA13 and career economic needs statements a medium relationship was found between SA13 and SB1, SB2, SB3 $(r=0.4-0.6 ; p=0.000(p<0.001))$. It shows that students use knowledge of the world to understand conversations, TV or radio shows, or movies in English to find a better job and to prepare for a future profession. A medium relationship was found between reading SA16 and career - economic need SB1, SB2, SB5 $(r=0.4-0.6 ; p=0.000(p<0.001))$ statements. The correlation coefficient $p=0.000(p<0.001)$ indicates that the linear relationship of the variables is significant. This shows that the more students understand the text being read; the more motivated the profession is to find a better job with a good salary. Exploring the relationship between students' English reading skills statement SA17 and career economic need statements SB1, SB2, SB4, SB5, it was found a statistically significant relationship $(r=0.4-0.6 ; p=0.000(p<0.001)$. This means that careful reading is associated with motivation to improve one's career by finding a better job with a higher salary after graduation. The speaking skills statements and career economic need statement weakly correlate with each other. There is a weak correlation between SA1 and SB1 $(r=0.2-0.4$; $p=0.000(p<0.001))$, SA1 and SB2 $(r=0.2-0.4 ; p=0.000(p<0.001))$. This shows that students tend to engage in dialogue as this is weakly related to the prospects of better work. 
Table 1

The correlation between English language skills and career - economic, cultural understanding needs $(p<0,001)$

\begin{tabular}{|c|c|c|c|c|c|c|c|c|c|c|}
\hline \multirow{2}{*}{$\begin{array}{c}\text { English learning } \\
\text { skills (A) }\end{array}$} & \multicolumn{5}{|c|}{ Career-economic need (B) } & \multicolumn{5}{|c|}{ Cultural understanding need (B) } \\
\hline & SB1 & SB2 & SB3 & SB4 & SB5 & SB6 & SB7 & SB8 & SB9 & SB10 \\
\hline \multicolumn{11}{|l|}{ Speaking skills } \\
\hline SA1 & 0.373 & 0.365 & & & & 0.362 & & & 0.361 & \\
\hline \multicolumn{11}{|l|}{ Writing skills } \\
\hline SA6 & 0.422 & & & & 0.329 & 0.477 & & & & \\
\hline SA9 & 0.391 & & & & & & & & & \\
\hline SA10 & 0.410 & 0.388 & & & & 0.436 & & 0.397 & 0.361 & 0.379 \\
\hline \multicolumn{11}{|l|}{ Listening skills } \\
\hline SA13 & 0.462 & 0.455 & 0.440 & & 0.398 & 0.531 & 0.388 & 0.462 & 0.380 & 0.414 \\
\hline SA15 & 0.537 & 0.499 & 0.413 & 0.509 & 0.437 & 0.396 & 0.407 & 0.363 & & \\
\hline \multicolumn{11}{|l|}{ Reading skills } \\
\hline SA16 & 0.454 & 0.459 & & 0.372 & 0.431 & 0.404 & & 0.402 & & 0.360 \\
\hline SA17 & 0.531 & 0.508 & 0.369 & 0.516 & 0.522 & 0.415 & 0.475 & 0.402 & & 0.374 \\
\hline
\end{tabular}

The correlation between English skills and the need for cultural - understanding. Mostly correlate reading skills and listening skills (Table 1). A medium relationship between reading SA17 and cultural understanding need SB6, SB7, SB8 $(r=0.4-0.6 ; p=0.000(p<0.001))$ statements was found to exist. The correlation coefficient $p=0.000(p<0.001)$ indicates that the linear relationship of the variables is significant. Students are more confident in the perception of the text to understand other cultures. A medium relationship was also found between the statements SA16 and SB6, SB8 $(r=0.4-0.6 ; p=0.000(p<0.001))$. It can be assumed that reading texts about other cultures, for example, in English textbook "Culture" section, deepens cultural understanding. A medium relationship was found to exist between listening SA13 and cultural understanding need SB6, SB7 $(r=0.4-0.6 ; p=0.000(p<0.001))$ statements. This shows that watching or listening to English helps to understand other cultures and gain confidence. A statistically significant relationship was found between SA15 and SB6 $(r=0.4-0.6 ; p=0.000(p<0.001))$. This shows that the more knowledge is used to understand TV, radio shows, or movies, the easier it is to understand the specifics of a foreign culture. A medium relationship was found between writing SA6 and cultural understanding need SB6 statements $(r=0.4-0.6 ; p=0.000(p<0.001))$. This shows that students choose essay topics that help them understand other cultures. A medium correlation between SA6 and SB6 $(r=0.4-0.6 ; p=0.000(p<0.001))$ statements was also found to exist. This suggests that students choose a writing model based on cultural context. For example, to write an invitation in English, students need to follow certain English language rules. It was found that there is a weak relationship between speaking SA1 and cultural understanding SB6, SB9 $(r=0.2-$ $0.4 ; p=0.000(p<0.001))$. This shows that dialogue learning is necessary to make connections with foreigners and understand the characteristics of their culture.

The relationship between English language skills and communication and collaboration needs with foreigners and self-satisfaction needs

The correlation between English skills and communication and collaboration needs with foreigners. Mostly correlate reading and listening skills (Table 2). A medium relationship was found between reading (SA16) and communication and collaboration needs (SB11, SB12, SB13) $(r=0.4-0.6$; $p=0.000(p<0.001))$. This shows that students use knowledge of the sequence of events to understand the text to communicate with foreigners in English language. SA17 and SB11, SB12, SB13, SB15 $(r=0.4-0.6 ; p=0.000(p<0.001))$ statements. This shows that students develop reading skills to make contacts and communicate with foreigners in their common language. Also, they learn to read on trips to foreign countries because essential information in foreign countries is provided in English. Also, a medium relationship was found between listening SA13 and communication, and collaboration needs SB11, SB13 $(r=0.4-0.6 ; p=0.000(p<0.001))$ statements. This shows that students, who watch English films, listen to radio programs, have a need to communicate with foreigners and cooperate more easily in their mother tongue. A medium relationship was found between SA6 and SB12 $(r=0.4-0.6$; $p=0.000(p<0.001))$ statements. This shows that students choose essays on the topic of which they have the most knowledge, and such knowledge of English encourages communication in correspondence with a foreigner. There was also a weak correlation between writing SA6 and SB13, 
SA10, and SB13. This shows that students tend to choose a topic that will be useful for communicating in English in the future.

Table 2

The correlation between English language skills and communication and collaboration needs with foreigners and self - satisfaction need $(p<0,001)$

\begin{tabular}{|c|c|c|c|c|c|c|c|c|c|c|}
\hline \multirow{2}{*}{$\begin{array}{l}\text { English learning } \\
\text { skills (A) }\end{array}$} & \multicolumn{5}{|c|}{$\begin{array}{c}\text { Communication and collaboration need } \\
\text { with foreigners' (B) }\end{array}$} & \multicolumn{5}{|c|}{ Self - satisfaction need (B) } \\
\hline & SB11 & SB12 & SB13 & SB14 & SB15 & SB16 & SB17 & SB18 & SB19 & SB20 \\
\hline \multicolumn{11}{|c|}{ Speaking skills Writing skills } \\
\hline SA6 & & 0.429 & 0.399 & & & & & & & \\
\hline SA10 & & & 0.388 & & 0.386 & & 0.363 & & & \\
\hline \multicolumn{11}{|l|}{ Listening skills } \\
\hline SA11 & & 0.385 & 0.349 & & & & & & & \\
\hline SA13 & 0.420 & 0.379 & 0.424 & & & & 0.489 & & 0.499 & 0.392 \\
\hline SA15 & & 0.444 & 0.443 & & 0.386 & & & & & 0.406 \\
\hline \multicolumn{11}{|l|}{ Reading skills } \\
\hline SA16 & 0.427 & 0.446 & 0.461 & & & & & & & \\
\hline SA17 & 0.500 & 0.479 & 0.609 & & 0.454 & & 0.426 & & & \\
\hline SA18 & & & & & & 0.367 & & & & \\
\hline
\end{tabular}

The correlation between English skills and self-satisfaction needs. The medium relationship was found between listening SA13 and self-satisfaction need (Table 2). SB17, SB19 $(r=0.4-0.6 ; p=0.000$ $(p<0.001))$ statements. This shows that students use their knowledge of the world to understand movies and information online in English. Also, between SA15 and SA20 $(r=0.4-0.6 ; p=0.000(p<0.001))$ This shows that students are carefully developing their listening skills to pass the exam. A medium relationship between reading SA17 and self-satisfaction need SB17 statements was found to exist. This shows that efforts are being made to develop reading skills by understanding unclear parts of the text to be able to read information online in English. There was a weak correlation between writing SA10 and self-satisfaction SB17 $(r=0.2-0.4 ; p=0.000(p<0.001))$ statements. This shows that students tend to choose the right model of the written text on the internet. No correlation was found with the significance level $(p<0.001)$ between speaking skills and self-satisfaction need.

The relationship between English language skills and self-confidence and integration with other culture needs

The correlation between English skills and self-confidence need. Most correlate reading and writing skills (Table 3). A medium relationship was found between reading SA16 and self-confidence SB24, SB25 statements, and SA17 and SB25 $(r=0.4-0.6 ; p=0.000(p<0.001))$. This shows that students read the text so carefully and self-confidently when the English teacher notices their progress as well. Noticing a teacher's progress in understanding unclear parts of the text causes positive emotions.

Table 3

The correlation between English language skills and self-confidence and integration with other culture needs $(p<0.001)$

\begin{tabular}{|c|c|c|c|c|c|c|c|c|c|c|}
\hline \multirow{2}{*}{$\begin{array}{c}\text { English learning } \\
\text { skills (A) }\end{array}$} & \multicolumn{5}{|c|}{ Self-confidence need (B) } & \multicolumn{5}{|c|}{ Culture integration need (B) } \\
\hline & SB21 & SB22 & SB23 & SB24 & SB25 & SB26 & SB27 & SB28 & SB29 & SB30 \\
\hline \multicolumn{11}{|c|}{ Speaking skills Writing skills } \\
\hline SA10 & 0.427 & 0.406 & 0.381 & & 0.414 & & 0.373 & & 0.418 & \\
\hline \multicolumn{11}{|l|}{ Listening skills } \\
\hline SA12 & 0.419 & 0.377 & 0.383 & & & & & & & \\
\hline SA13 & & & & & & & 0.404 & & & \\
\hline SA15 & & & & & & & 0.398 & & & \\
\hline \multicolumn{11}{|l|}{ Reading skills } \\
\hline SA16 & & & & 0.406 & 0.427 & & & & & \\
\hline SA17 & & 0.394 & & & 0.513 & & 0.383 & & & \\
\hline SA19 & & & & 0.390 & & & & & & \\
\hline
\end{tabular}


Also, a medium correlation was found between writing SA10 and SB21, SB22 and SB25 $(r=0.4-0.6$; $p=0.000(p<0.001))$ statements. More practical writing skills are developed. the freer communication in the classroom, and the positive insights of the teacher encourage writing skills. A medium relationship was found between listening SA12 and SB21 $(r=0.4-0.6 ; p=0.000(p<0.001))$ statements. This shows that refining and understanding the speaker's language allows for freer English communication in the classroom. No correlation was found with the significance level $(p<0.001)$ between speaking skills and self-confidence need.

The correlation between English skills and the need for integration with other cultures. Mostly correlate writing and listening skills (Table 3). A medium relationship was found between writing SA10 and cultural integration need SB29 $(r=0.4-0.6, p=0.000(p<0.001))$ statements. Learning a foreign language helps students to prepare for living in another country. This shows that learning to apply a proper writing model is associated with emigration. Students believe that the completion of documents in English is the most needed when traveling abroad. Also, medium relationship was found between listening SA13 and cultural integration need SB27 statements $(r=0.4-0.6, p=0.000(p<0.001))$. This shows that students learn English by watching movies, listening to radio shows to communicate with foreigners in English. There was also a weak correlation between SA15 and SB27 $(r=0.2-0.4$; $p=0.000(p<0.01))$. A weak correlation was found between reading SA17 and need for integration with other cultures SB27 statements $(r=0.4-0.6, p=0.000(p<0.001))$. This shows that listening skills are developed to understand people from other cultures. No correlation was found with the significance level $(p<0.001)$ between speaking skills and the need for integration.

This analysis shows how students are integrated into English language learning. It is agreeable with R. Gonzales and M.Y. Lopez $(2016,18)$ research that learning depends on learner's motivation, on the other hand, the foreign language teacher must be enthusiastic in performing his or her job well. This research showed a correlation between English skills and learning needs. Comparing to T.M. Thu (2009) research and this research disclosed English learning skills of secondary school students. It is agreeable that all learning skills depend on practice and students learning motivation. Students' English learning the needs are similar to needs of D. Poedjiastutie and R. Oliver (2017) study. Students learn English to be: a) competitive in the employment market; b) be able to participate in international collaboration, and c) improve their life opportunities. F. Aziz and U. Quraishi (2017) study shows that spoken English would be learnt well by students. They agreed that for finding better jobs, competence in English is necessary.

\section{Conclusions}

The analysis disclosed that mostly correlated English skills are reading and listening skills. Reading skills medium correlate with cultural economic needs. Reading skills help to prepare for the future to find a better job with a good salary. Also, reading skills also correlate with cultural understanding need. Students read English texts to understand other cultures. A medium correlation was found between reading and communication and collaboration needs. Reading skills help to make contacts and communicate with foreigners in their common language. Also, reading skills medium correlate with self-confidence need skills. Students are self-confident when they are ensured in their knowledge and the English teacher notices their progress. Listening skills medium correlate with career economic need. Students develop listening skills to understand conversations, TV or radio shows, or movies in English or to find a better job in the future. Also, listening skills mostly medium correlate with cultural understanding need. Students watch or listen to in English to understand other cultures. Besides that, listening skills correlate and with self-confidence needs. Students use their listening knowledge of the world to understand movies and information online in English. The writing skills mostly correlate with cultural integration needs. Students learn writing to live abroad in the future. No correlation was found between speaking skills and the chosen level of significance with all needs, except between careereconomic, cultural understanding it was found a weak correlation. Moreover, learning English depends on learner's motivation, on the other hand, the foreign language teacher must be enthusiastic in performing his or her job well. We can assume that students give the most priority to comprehension skills - reading and listening than to communicative skills - writing and speaking. In the future, the research is planned to develop more widely. 


\section{Bibliography}

1. Aziz F., Quraishi U. (2017). An insight into secondary school students beliefs regarding learning English language. Cogent Education, 4(1), 1-9. doi: 10.1080/2331186X.2017.1278835

2. European Commission. (2018). Proposal for a Council Recommendation on Key Competences for Lifelong Learning. Retrieved from https://eur-lex.europa.eu/legalcontent/EN/TXT/PDF/?uri=CELEX:52018SC0014\&from=EN

3. Gardner R.C. (2010). Motivation and second language acquisition: The socio-educational model. New York: Peter Long Publishing.

4. Gonzales R., Lopez M.Y. (2016). Foreign language learning motivation questionnaire: Further examination of a six-factor model. In A.B.I. Bernardo (Ed.), Counseling, psychology, and education: A Festschrift in honor of Rose Marie Salazar-Clemeña, 1-25. Manila, Philippines: De La Salle University Publishing House.

5. Hauke J., Kossowski T. (2011). Comparison of values of Pearson's and Spearman's correlation coefficients on the same sets of data. Quaestiones Geographicae, 30(2), 87-93. doi: 10.2478/v10117011-0021-1

6. Horgan J.J. (2017). Using critical incident analysis to develop form 11 English as a foreign language students' self-reflection skills and conditional phrase usage incident. In V. Dislere (Ed.), The Proceedings of the International Scientific Conference Rural Environment. Education. Personality (REEP), 10. Jelgava: LLU, 84-91. Retrieved from https://llufb.llu.lv/conference/REEP/2017/LatviaUniv-Agricult-REEP-2017_proceedings-84-91.pdf

7. Kardelis K. (2002). Moksliniu tyrimu metodologija ir metodai [Research methodology and methods]. Kaunas: Judex (in Lithuanian).

8. Lani J. (2010). Conduct and interpret a spearman rank correlation. Retrieved from https://www.statisticssolutions.com/wp-content/uploads/kalins-pdf/singles/spearman-rankcorrelation.pdf

9. Lin L.F. (2017). Impacts of the problem-based learning pedagogy on English learners' reading comprehension, strategy use, and active learning attitudes. Journal of Education and Training Studies, 5(6), 109-125. doi: 10.11114/jets.v5i6.2320

10. Manegre M., Gutiérrez-Colón M. (2020). Foreign language learning through collaborative writing in knowledge building forums. Interactive Learning Environments, Advanced online publication. doi: 10.1080/10494820.2020.1836499

11. Maslow A.H. (2006). Motyvacija ir asmenybe [Motivation and personality]. Vilnius: Apostrofa. (in Lithuanian)

12. Meinawati E., Harmoko D.D., Rahmah N.A., Dewi N. (2020). Increasing English speaking skills using Youtube. Polyglot: Jurnal Ilmiah, 16(1), 1-13. doi: 10.19166/pji.v16i1.1954

13. Molway L., Mutton T. (2019). Changing mindsets in the modern foreign languages classroom: an intervention combining intelligence theories and reading strategies. The Language Learning Journal, 48(5), 598-612. doi: 10.1080/09571736.2018.1554693

14. Naidionova A.V., Ponomarenko O.G. (2018). Use of podcasting technology to develop students' listening skills. Information Technologies and Learning Tools, 63(1), 177-185. doi: 10.33407/itlt.v63i1.1962

15. Poedjiastutie D.,Oliver R. (2017). Exploring students' learning needs: Expectation and challenges. English Language Teaching, 10(10), 124 -133. doi: 10.5539/elt.v10n10p124

16. Richards J.C. (2001). Curriculum development in language teaching. New York: Cambridge University Press. doi: 10.1017/CBO9780511667220

17. Rupšienè L., Rutkienè A. (2016). Edukacinis eksperimentas [Educational experiment]. Klaipèda: Klaipedos universitetas (in Lithuanian).

18. Thu T.M. (2009). Learning strategies used by successful language learners. Online Submition. Retrieved from https://eric.ed.gov/?id=ED507398

19. Williams F., Monge P. (2001). Readings with statistics: How to read quantitative research $\left(5^{\text {th }}\right.$ ed.). Fort Worth, TX: Harcourt College Publishing.

20. Zhang Z.V. (2020). Learner engagement and language learning: a narrative inquiry of a successful language learner. The Language Learning Journal, Advanced online publication. doi: 10.1080/09571736.2020.1786712 